GEOGRAFICKÝ ČASOPIS / GEOGRAPHICAL JOURNAL 73 (2021) 2, 125-142

DOI: https://doi.org/10.31577/geogrcas.2021.73.2.07

\title{
POST-1990 MIGRATION BIOGRAPHIES OF SLOVAKS FROM VOJVODINA: A TIME-GEOGRAPHIC PERSPECTIVE
}

\author{
Vladimír Ira*, Ana Uher* \\ * Institute of Geography of the Slovak Academy of Sciences, Štefánikova 49, 81473 Bratislava, Slovakia, \\ geogira@savba.sk, ana.uher77@gmail.com
}

\begin{abstract}
Post-1990 migration biographies of Slovaks from Vojvodina: A time-geographic perspective

Migrants' life history, whose life-paths were affected by significant political and social events, is one of the academic research interest in human geography, social science, and humanities. The aim of this paper is to illustrate how the time geography could be used as an approach to identify individuals' behavioural patterns. Data were collected from a small sample of Slovaks from Vojvodina $(n=34)$ and subsequently analysed in relation to certain situations in time and space (place). Semi-structured interviews and time-space records were used in constructing 3D life-paths and life chart. Using time geography approach we provide a certain amount of information enabling generation of a broader picture of person's life to identify social, economic and behavioural aspects (including motivation to migrate) affected in some cases by war conflicts in former Yugoslavia, in others by post-war subsequent political, legal, social and economic changes. The findings of the research show that this kind of ,the life-path schemes" helps describe a detailed life situation from one time period to another, where geographical sites serve as important „stations“ for Slovaks from Vojvodina who decided to spend a longer period in Slovakia or to settle down in a new homeland.
\end{abstract}

Key words: migration, time-geography, life-paths, time-space records, Slovaks from Vojvodina

\section{INTRODUCTION}

International migration is currently a characteristic manifestation of globalizing processes and a significant attribute of global change in an increasing number of countries. It is considered one of the fundamental civilization challenges of the $21 \mathrm{st}$ century due to its economic, social, population, cultural, political, security, environmental and other impacts. The majority of people migrate internationally for reasons related to work, study and family. In contrast, other people leave their homes and countries for a range of compelling and sometimes tragic reasons, such as war conflict, persecution and marginalization (IOM 2019)

The study of historical migration of contemporary Slovaks from the "Lower Land", originally coming from Upper Old Hungary, is a relatively frequent topic. Mostly when examining the diversity of the origin of Slovak settlers, it is approached from a historical, historical geographic or cultural, especially ethnographic aspect (e.g. Siracký 1980, Benža et al. 2006, Gurňák 2007, Botík 2011 and Filadelfi 2012), where factual reference is made to migrations in the 18th and 19th centuries and their intention to repopulate the Lower Hungary and the present-day Vojvodina. We follow an interest in this topic mainly among Slovak experts and then in the circles of Vojvodina experts, mostly from the first half of the 20th century. Unfortunately, scientific works with a similar focus, but currently already oriented towards movements in the opposite direction, when the descendants of the 
Vojvodina Slovaks migrated back to Slovakia, especially since the end of the 20th century to the present, are only few (e. g. Zlatanović and Marušiak 2017, Surová 2016 and 2018 and Marušiak and Zlatanović 2020). For these reasons, we will not be able to rely on numerous credible academic sources treating this issue, but we will focus on our own time-space (geographical) research supplemented by the knowledge from ethnological, sociological and political science research.

Our ambition is to make this new phenomenon visible from the point of view of time-geography and to examine the biographical records of a selected sample of Slovaks from Vojvodina. The aim is to illustrate how the time-geographical approach using spatio-temporal diary data and semi-structured interviews may be used to illuminate the impact of the changing conditions in Vojvodina, an autonomous province in northern Serbia, in the post-1990 period (until 2018) in order to understand the geographical aspects of the migratory behaviour of Slovaks from Vojvodina and their motives to spend a longer period in Slovakia or to settle down in a new homeland. The study also suggests the effects of migration on life paths trying to articulate their "emotional geographies" in the studied period.

\section{THEORETICAL BACKGROUND}

Migration plays a critical part in people's life-paths, usually being associated with major life changes (Boyle 2009). For those moving abroad, migration can represent significant changes including separation from broader family and friends, loss of the familiar and close environment (including landscape), the stress of the move itself, and the potential difficulties associated with coming to milieu with a different cultural and socio-political setting. Although the vast majority of migrants are motivated by a desire for better economic opportunities and a higher standard of living for themselves and their families, some are forced to leave due to armed conflict and other causes. (Divinský 2007 and Divinský and Zachar Podolinská et al. 2018). Over 82 million international migrants lived in Europe in 2019. A little over half of these (42 million) were born in Europe but were living elsewhere in the region. This number has increased since 1990. It was much lower, at around 28 million (IOM 2019). For most South-Eastern European countries, emigration rather than immigration has been the key feature over recent decades. "Through migration different communities are linked together in more or less formal adaptation of flows and the implications of these streams may impact on both the migrants and the places through or to which they move" (Boyle 2009, p. 96). The approaches of geographers taken to understand population migration are theoretically and empirically diverse (Drbohlav and Uherek 2007 and Boyle 2009). Remigration (or reemigration), which means the act or process of returning or migrating back to the place of origin (origin of ancestors) is a specific case of migration (Janská and Drbohlav 2009).

During the late 1960s and 1970s, behavioural geographical thought influenced the approach to the study of migration by stressing the mechanisms behind the individual acts of migration and put the individual agent at the heart of the process. The role of perceptions and the limits of the rational decision making model were emphasized in these approaches. It was supposed that people do not always take perfect or rational decisions (Golledge and Stimson 1997). This encouraged more qualitative approaches to be adopted (e. g. focused attention on the beliefs, aspirations, constraints, etc.). 
Migration is a complex and multifaceted process and thus the concept of migration is becoming more "fluid" than it was assumed in the past. This paper focuses on the issue of migration from the perspective of time-geography and so the key aspect will be the study of life-paths and their important segments. Timegeography is one way of thinking about a hybrid time-space (Merriman 2012). Time-geographical approach concerns trajectories in time and space of individuals and groups (Hägerstrand 1967). "Time-geography rests on the premise that each of the actions and events consecutively occurring between the birth and death of an individual has both temporal and spatial attributes, thus the biography of a person is ever on the move with her and can be conceptualized and diagrammed at daily and lengthier scales of observation as an unbroken, continuous path through timespace ..." (Pred 1981, p. 9).

The continuous flow of time cannot be halted. In time-geography, the lifetime of every human being as an indivisible unit is anchored in the historic time dimension from the moment of birth until death. The life experiences of two individuals are logically (naturally) different. The specific differences, among other things, depend on what happened in society (or specific milieu) during their lives (Ellegård 2018). The path is a fundamental concept in time-geography. The combination of the path and individual concepts into individual path reveals that the path illustrates the time-space movements of an individual. It can be used to visualize the movements of individuals and it works on various scales in time and space. Several authors underline that the path is an abstract illustration of the time-space movements of an individual (Lenntorp 1999, Ira 2001, Lundén 2003 and Pred 2005), while the individual represented by the path is something much more complex (Ellegård 1999 and 2018). In one sense the life-path can be read as diagrams of choices made by individuals, in another sense they depict constraints on the movements of people (Cresswell 2013). The path can be regarded as a flow of events, experienced by a human individual as his/her activity sequence. "The path can indicate the individual's getting in touch with other individuals, staying at a place doing something together with them, and leaving it afterwards" (Ellegård 2018, p. 30).

The very idea of life-paths shaped Torsten Hägerstrand's geographical thoughts. His first research task was to 'trace the life from year to year' of 10,000 people who inhabited his home parish during 100 years. He succeeded in condensing the whole life story in one diagram; Hägerstrand subsequently developed the paths and projects of time-geographic as a 'scientific observer', and later Hägerstrand's perspective on the 'paths and projects' of time-geography incorporated memories, feelings, knowledge, imagination and goals as elements of a 'living landscape' (Daniels and Nash 2004).

The focus of the time-space records is to gain knowledge about opportunities and constraints at the individual level, which can be used for many purposes (Ellegård 2019). The time-space record (time-space activity diary) is not only a significant instrument for a sensible analysis of everyday life but also for life-paths analysis of individuals (Frändberg 2008). The use of time-space records expanded after the introduction of Hägerstrand's time-geography into human geographical research (Hägerstrand 1970). The development of the geographic information systems (GIS) and computational capabilities in the last few decades facilitate the analysis of time-space records (Couclelis 1999). 


\section{STUDY AREA}

Vojvodina is an autonomous province in northern part of Serbia (Fig. 1) bordered by Croatia (West), Hungary (North) and Romania (East). It covers an area of 21,614 square $\mathrm{km}$ and has a population of 1.932 million (2011). Most of the territory consists of an extensive plain that is part of the Pannonian Basin. Vojvodina includes 3 historic regions (Bačka, Banat and Srem). Vojvodina is divided into seven districts that are further subdivided into 45 municipalities (https:// www.sio.vojvodina.gov.rs/index.php/linkovi/linkvi-opstine) and 8 towns or cities. As far as the ethnicity is concerned, the province is very diverse with more than 25 ethnic groups. Six languages (including Slovak) are in the official use by the provincial administration. Slovaks living in Vojvodina are the ethnic group, the existence of which is the result of historical migration with the beginning in the late eighteenth century. The Ottoman Turks controlled the region from the early 16th to the late 18th century. With the region's incorporation into the Austrian Habsburg empire later in the 18th century, large numbers of Slovaks also migrated to the area. Sirácky (1980) defines three stages of migration: first stage - colonization of the Lower Lands (1690 - 1710), second stage - colonization of settlements in Hungary $(1711$ - 1740) and the third stage - the colonization of settlements in Vojvodina $(1745-1790)$. At the time of the third stage, the southernmost part of Hungary was settled - Bačka, Banat and Srem (Filadelfi 2012). Bački Petrovac (Báčsky Petrovec in Slovak) was the first to be settled in 1745. Until today, it has a strong Slovak character and is an important cultural centre of Slovaks in Vojvodina. Descendants of Slovak migrants have lived in the territory of Vojvodina for more than two and a half centuries. Many have kept the language and faith of their ancestors. They have maintained Slovak traditions and culture despite external pressures (Surová 2018). According to the 2011 census (Statistical Office of the Republic of Serbia 2013), Slovaks in Serbia constitute $0.7 \%$ of country's population and mainly live in Vojvodina $(50,321)$.

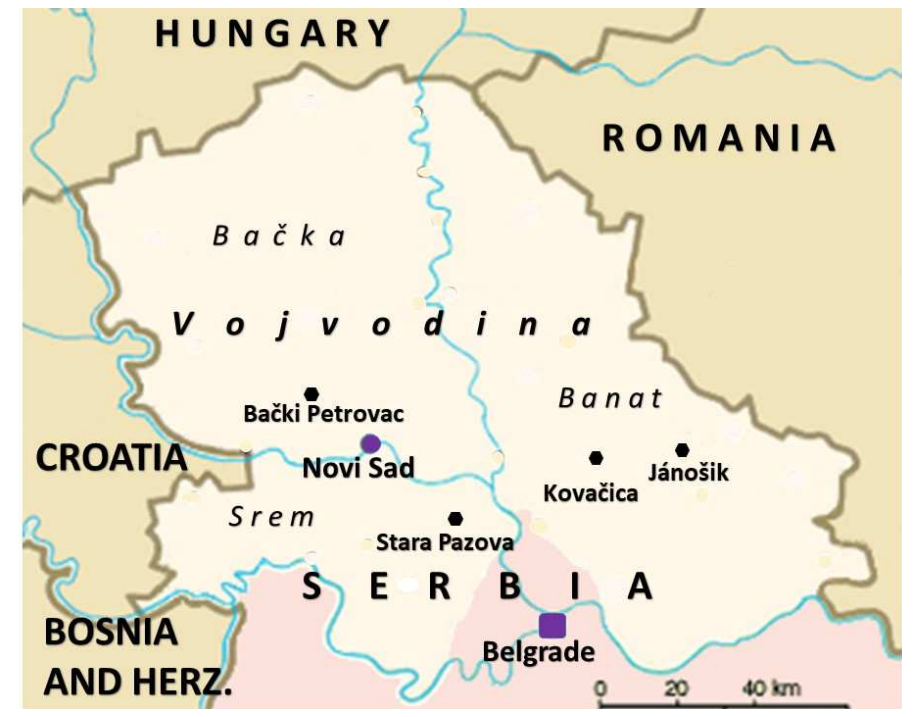

Fig. 1. Schematic map of Vojvodina with important names of localities and regions mentioned in the text 
Most of them are Protestants, especially members of the Lutheran Church. Most Slovaks live in Kovačica $(10,577)$ and Bački Petrovac $(8,772)$. Both towns are the cultural centres of Slovaks in Vojvodina (Fig. 1). Most members of the Slovak community in Vojvodina speak the Slovak language. They have the right to education in their mother tongue.

The modern history of Vojvodina at the end of the 20th and the beginning of the 21 st century was marked by war conflicts. The wars in former Yugoslavia from 1991 to 2001 were a series of separate but related ethnic (and in some cases also religious) conflicts, wars of independence and insurgencies. In 1992 it resulted in the breakup of the Yugoslav federation. Unresolved tensions resulted in declaration of new constituent republics. After the breakup of former Yugoslavia, civil war, and bombing of the country in 1999 by the NATO, many Slovaks migrated from Vojvodina (Serbia) to Slovakia. Slovakia provided preferential treatment in the areas of residency, work, education, healthcare system, and citizenship acquisition to foreign Slovaks (Zákon č. 70/1997 Z.z. o zahraničných Slovákoch, Zákon č. 474/2005 Z.z. o Slovákoch žijúcich v zahraničí a o zmene a doplnení niektorých zákonov). "Some Slovaks from Serbia stayed in Slovakia permanently, some of them migrated further to other states while some returned back to Serbia. Many of them acquired either Slovak living abroad certificate or citizenship or both for various reasons"(Surová 2016, p. 6).

\section{DATA AND METHODS}

In this article, we apply the mixed-methods approach using time-space records (diaries), semi-structured interviews and simple observations. The union of the qualitative and quantitative methods and a focus on the specific with different geospatial technologies leads to innovative and exciting ways of understanding and visualizing the multifaceted relationships between spatial phenomena (Yeager and Steiger 2013).

Qualitative research is the collection of information about human behaviour and perception. It is about focusing in depth to find out why and how certain activities and events occur. In our study the observation was applied as a way of collecting data through observing. Observation data collection method we understand as a participatory study. Data collection in the semi-structured or semi-systematic observation was conducted partially using specific variables (on the time-space behaviour and the behaviour in time-space) and according to a pre-defined schedule. Advantages of observation data collection method included high levels of flexibility in terms of application and generating a permanent record of phenomena and direct access to research phenomena (Hai, ed. 2016). In the case of research among Slovaks from Vojvodina, it was a participatory observation. During this observation, the observer entered the group (in some cases in Vojvodina, in others in Slovakia, especially in Bratislava) of subjects and became an active member of the group. It was a more comprehensive examination of the group, the task of which was to reveal the internal perspective of the participants.

In order to collect survey data, we used the time-geographical approach which is based on records of activities that have taken place in a certain time and space. Time-space records (time-space activity diaries) in our survey enabled to collect information on: (1) the activity content: the time that an activity episode starts and ends (when), (2) the geographical context, i.e. the spatial location where the activi- 
ty takes place (where), (3) the social context, i.e. the person(s) involved in the event (with whom), and (4) the use of transportation mode(s) enabling access the place where the activity occurs (how). There were several additional aspects for which information was collected (motivations to move and respondent's feelings and emotions during activities (Schwanen, 2009). This method recording individuals' activities and movement in time and space may facilitate reflections on changes in the patterns of activities and may enable a deeper understanding of relationships in the community (Díaz-Muňoz et al. 1999 and Ellegård 2019). It illustrates practices and activities in geographical and social context. The diary method provides an effective approach to collect data that enable the systematic study of the life activities of individuals and was applied in several scientific disciplines (e.g. Schwanen, 2009, Schwanen and Kwan 2012, Ellegård 2019, and Sunnqvist et al. 2020).

The participants filled out the time-space records and then participated in interviews to discuss them. We have conducted semi-structured interviews, a method of inquiry in which we specified and asked our participants a set of questions, but the order and way we asked the questions may have varied.

The life charts technique was also used in our study. Time geographical life charts activate autobiographical memories by merely asking about geographical moves through life. E.g. Sunnqvist et al. (2007 and 2020) explored the use of time geography life charts in clinical psychiatric practice. The life charts provide an information on the person's sociocultural capacity, as well as on stressful or challenging (difficult to solve) life events. This technique makes it possible to recall and discuss difficult political, economic and social situations and stressful events in order to obtain a comprehensive picture of the entire life situation. This method could give the researcher deeper knowledge than otherwise possible. The timegeography life chart strengthens the comprehensive picture of the respondent's life situation.

Snowball sampling is a method that has been used in social sciences to study sensitive topics (Cohen and Arieli 2011). Snowball sampling is a nonprobability sampling technique where existing study subjects recruit future subjects from among their acquaintances (e.g. Goodman 1961 and Rochovská et al. 2014). The sample group grows like a rolling snowball. The method applied in our research involved the selection of sample of Slovaks from Vojvodina utilizing "insider" knowledge and referral chains among subjects who possess common traits that are of research interest (Kaplan et al. 1987).

\section{RESULTS}

In this article we analyse the activity patterns of a selected group of 34 Slovaks from Vojvodina, who currently live in Slovakia. Fifteen men and a slightly larger sample of nineteen women (average age 44.6 years in 2018) were in this group. From the total number of 34 respondents we selected 4 persons (two females and two males) with considerably different life destinies and on the example of their life-paths we analysed in more detail the complexity of their behavioural patterns through two techniques (3D graphs in Figs. $2-4$ and one life chart in Fig. 5). The data allowed us a new insight into the their behaviour. It contributes to understandding of activities of people affected by specific political, economic, socio-cultural, institutional, and geographical factors in a Euclidean space and time. 
Important aspects of the time-space behaviour of all thirty-four interviewees are presented in Tab. 1. Almost three decades of our analysis were divided into three periods: pre-war period in Vojvodina (January 1st 1990 - April 6th 1992), war time (April 7th 1992 - December 14th 1995) and post-war period (December 15th 1995 - April 16th 2018) ending in the time when survey was completed. Among motivational reasons of Slovaks from Vojvodina for a long-term or permanent residence in Slovakia we can find in most cases either continuation in a higher education (all university degree levels) or finding jobs that give them much better financial opportunities (working as managers in big corporations, IT specialists, teaching at universities, specialist in various fields such as software engineering in security service or computer programming). There were also security concerns influenced by the experience, especially during the toughest military interventions in 1991 - 1995. After 1995, our respondents also travelled to other countries around the world (Australia, Denmark, Ireland, South Korea, Switzerland, United Kingdom, and USA); mainly for reasons of completing various study stays (Czechia, Ireland, and United Kingdom), longer visits of the relatives (in Canada, Germany, and the USA) or job specialization (Qatar, South Korea, and Switzerland). They mostly returned to Slovakia. Respondents who decided to move to Slovakia in the post-conflict period after 2000, in most cases stated family reasons (marriage, family reunion, after completing university studies they started families and having children, so they decided to apply for a mortgage and stay) and a desire to continue higher education under more favourable conditions than in Serbia (university studies including doctoral education in Slovakia is for free). During their studies many took advantage of the possibility of a short stay abroad (Denmark, United Kingdom, and the USA).

As an example of visual interpretation of time-space records in 3D graphs we have selected three respondents of Slovak origin from Stara Pazova (Fig. 2), Bački Petrovac (Fig. 3), and Jánošik (Fig. 4). A selected group of 3 respondents represented by 1 woman and 2 men presents different types of life-paths influenced by different family backgrounds, life situations and other factors. Vertical axis in the graphs represents the temporal dimension (time context), duration of some activity in certain geographical contexts of one individual (expressed by other two dimensions). Every interruption or diversion meant change of direction of the movement. Time span used in the construction of 3D graphs was from 1990 until 2018. Evaluating the whole set of respondents, we can say that before the war there were no important changes in place of living recorded, on the contrary, in the post-war period, the movements were very frequent and many of them were directed to Slovakia. The life-paths of three selected respondents documented by $3 \mathrm{D}$ graphs (Figs. $2-4$ ) are analysed in more detail in the following paragraphs. In the case of the fourth respondent from Bački Petrovac $(39$, F), the 28-year segment of her life-path is analyzed in more detail through a life chart (Fig. 5).

A woman, 43 years old, from Stara Pazova, was interested in studying in Slovakia (Fig. 2). The war in the former Yugoslavia only hastened the decision. Thanks to her university studies (in Bratislava), she was able to spend more time in an au pair programme in Hørsholm, Denmark (September 1998 - July 1999). During her studies, she regularly returned home to her birthplace, where she spent months on vacation and in the autumn travelled back to Bratislava. After graduating from university in June 2000, she got a job in Bratislava, and since then there have been no reasons for the decision to return to Vojvodina. 
Tab. 1 Motivations of Slovak respondents from Vojvodina to move to Slovakia

\begin{tabular}{|c|c|c|c|}
\hline \multirow{2}{*}{$\begin{array}{l}\text { Age (in 2018), } \\
\text { Gender }\end{array}$} & \multicolumn{3}{|c|}{ Motivation to move } \\
\hline & $\begin{array}{c}\text { January } 1990- \\
\text { April } 1991\end{array}$ & $\begin{array}{c}\text { May 1991 } \\
\text { - December 14th, } 1995\end{array}$ & $\begin{array}{l}\text { December 15th, } 1995 \\
\text { - April 16th, } 2018\end{array}$ \\
\hline $35, \mathrm{M}$ & $\mathrm{OTt}$ & 0 & WO \\
\hline $32, \mathrm{~F}$ & 0 & 0 & $\mathrm{ED}, \mathrm{OT}, \mathrm{WO}, \mathrm{FA}$ \\
\hline $32, \mathrm{M}$ & 0 & 0 & $\mathrm{ED}, \mathrm{OT}$ \\
\hline $59, \mathrm{~F}$ & 0 & 0 & FA, WO \\
\hline $43, \mathrm{~F}$ & 0 & $\mathrm{ED}$ & ED, OT, WO \\
\hline $41, \mathrm{M}$ & 0 & 0 & ED, OT, WO, FA \\
\hline $60, \mathrm{M}-\mathrm{a}$ & 0 & WO & 0 \\
\hline $63, \mathrm{~F}$ & 0 & 0 & WO \\
\hline $39, \mathrm{~F}$ & 0 & 0 & ED, OT, WO \\
\hline $45, \mathrm{M}$ & 0 & $\mathrm{ED}, \mathrm{WO}$ & ED, OT, WO \\
\hline $54, \mathrm{M}$ & 0 & 0 & SE, WO, OT \\
\hline $41, \mathrm{M}$ & 0 & 0 & ED, WO \\
\hline $43, \mathrm{~F}$ & 0 & 0 & WO, FA \\
\hline $43, \mathrm{~F}$ & 0 & ED, FA & ED, WO, FA, OT \\
\hline $43, \mathrm{~F}$ & ED & ED & ED, wO \\
\hline $60, \mathrm{M}-\mathrm{b}$ & 0 & 0 & WO \\
\hline $31, \mathrm{~F}$ & 0 & 0 & ED, WO \\
\hline $53, \mathrm{M}$ & 0 & 0 & WO \\
\hline $37, \mathrm{~F}$ & 0 & 0 & ED, WO \\
\hline $43, \mathrm{~F}$ & 0 & ED & $\mathrm{ED}, \mathrm{WO}, \mathrm{FA}$ \\
\hline $32, \mathrm{M}$ & 0 & 0 & ED, WO, FA \\
\hline $51, \mathrm{~F}$ & 0 & 0 & WO, FA \\
\hline $40, \mathrm{M}$ & 0 & ED, FA & ED, WO, FA, OT \\
\hline $37, \mathrm{M}-\mathrm{a}$ & 0 & 0 & ED, OT \\
\hline $40, \mathrm{~F}$ & 0 & $\mathrm{ED}$ & WO, OT, WO, FA \\
\hline $37, \mathrm{M}-\mathrm{b}$ & 0 & FA, SE & ED, OT, WO, FA \\
\hline $38, \mathrm{~F}$ & 0 & 0 & $\mathrm{ED}, \mathrm{WO}, \mathrm{FA}$ \\
\hline $46, \mathrm{~F}$ & ED & ED & ED, WO, FA \\
\hline $63, \mathrm{~F}$ & 0 & 0 & WO, FA \\
\hline $47, \mathrm{M}$ & 0 & SO, wO & FA, WO \\
\hline $63, \mathrm{M}$ & SO & 0 & WO, FA \\
\hline $43, \mathrm{~F}$ & 0 & 0 & ED, WO \\
\hline $42, \mathrm{~F}$ & 0 & ED & WO \\
\hline $41, \mathrm{~F}$ & 0 & 0 & ED, OT, WO \\
\hline
\end{tabular}

Source: own research

Motivations: 0 - no reason to move, FA - Family, IN - Institution, SE - Security, EC - Economic (financial) reasons, WO - Work, ED - Education, MA - Marriage, LC - Living conditions, OT - Others

As an example of visual interpretation of time-space records in 3D graphs we have selected three respondents of Slovak origin from Stara Pazova (Fig. 2), Bački Petrovac (Fig. 3), and Jánošik (Fig. 4). A selected group of 3 respondents represented by 1 woman and 2 men presents different types of life paths influenced by different family backgrounds, life situations and other factors. Vertical axis in the graphs represents the temporal dimension (time context), duration of some activity in certain geographical contexts of one individual (expressed by other two dimensions). Every interruption or diversion meant change of direction of the movement. Time span used in the construction of 3D graphs was from 1990 until 2018. Evalu- 
ating the whole set of respondents, we can say that before the war there were no important changes in place of living recorded, on the contrary, in the post-war period, the movements were very frequent and many of them were directed to Slovakia. The life paths of three selected respondents documented by 3D graphs (Figs. $2-4)$ are analysed in more detail in the following paragraphs. In the case of the fourth respondent from Bački Petrovac $(39, \mathrm{~F})$, the 28-year segment of her life-path is analyzed in more detail through a life chart (Fig. 5).

A woman, 43 years old, from Stara Pazova, was interested in studying in Slovakia (Fig. 2). The war in the former Yugoslavia only hastened the decision. Thanks to her university studies (in Bratislava), she was able to spend more time in an au pair programme in Hørsholm, Denmark (September 1998 - July 1999). During her studies, she regularly returned home to her birthplace, where she spent months on vacation and in the autumn travelled back to Bratislava. After graduating from university in June 2000, she got a job in Bratislava, and since then there have been no reasons for the decision to return to Vojvodina.

Life path of man from Bački Petrovac $(60, \mathrm{M}-\mathrm{a})$ is visualized in Fig. 3. The reasons for immigrating to Slovakia were primarily of a private working nature. Conflicts during the 1990s had only an indirect effect on moving away. After immigrating to Slovakia in January 1993, he and his family changed housing several times during that year (Senec till February, after that Bratislava till May, Plavecký Stvrtok by mid-October). After that they moved back to Bratislava, where they live until now. If there were no wars and the subsequent disintegration of Yugoslavia, he would probably remain living in Vojvodina. At present, he no longer intends to go back.

Fig. 4 shows the life-path of man from village Jánošik $(37, M-b)$. The conflicts in the former Yugoslavia and the accompanying phenomena motivated him and his parents to move to Brezno (September 1991 - June 1994). After the wars in the 1990s, they returned to Jánošik (July 1994 - August 1998). He first attended Slovak grammar school in Jánošik. Then he continued his education at secondary schools. First two years he spent in the secondary school in Kovačica (September 1996 - August 1997) and the last two years in Bački Petrovac (September 1997 June 2000). Then he applied to the University in Novi Sad but he did not succeed in completing it (October 2000 - February 2003). From March till November 2003, he served in the Serbian Army (compulsory military service) for almost one year. Since he was unable to find a job after returning home, he decided to come to Bratislava, where he continued his university education, which he completed by defending his doctoral dissertation in June 2016. He is currently employed in public administration and has a family. The only reason why they would move out of Slovakia could be a "war conflict in Slovakia".

Twenty-eight years of life-path of a 39-year-old woman from Bački Petrovac are visualised in Fig. 5 (life chart). Conflict environments in the former Yugoslavia had a direct impact on her decision to leave Vojvodina. This has happened after the NATO bombing in 1999. She enrolled in the International Baptist Lay Academy in Budapest, Hungary (study from October 1999 to February 2000). She did not plan to go immediately to Slovakia, but first to the USA. Her decision changed after meeting her husband. Later, they decided together to settle in Slovakia. Due to her adventurous nature, in the past she tried to find a longer-term volunteer job in the United Kingdom. There she spent almost half a year (from February till August 2000) in several cities - Otford, Norwich, Leeds, Glasgow, Edinburg, and London. 


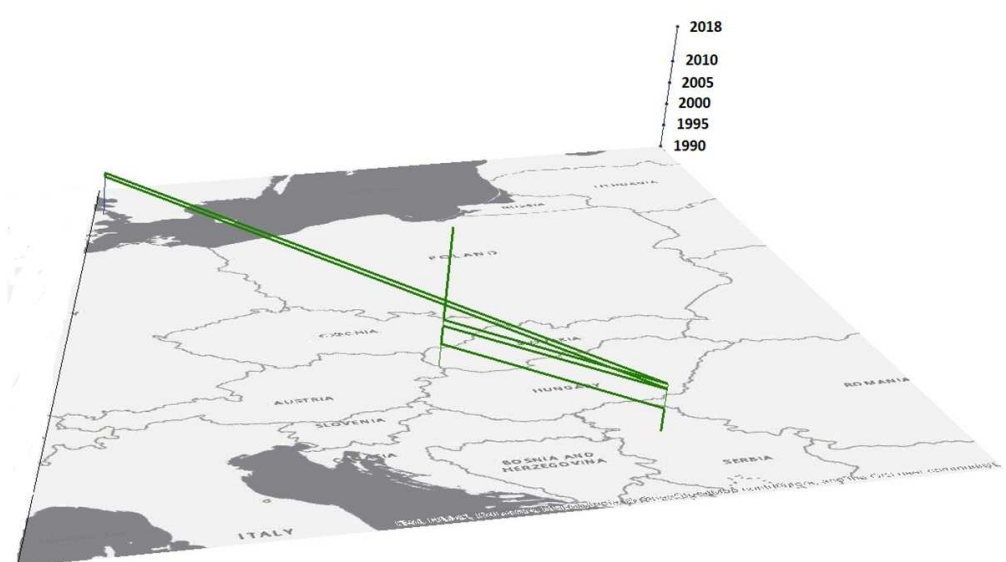

Fig. 2. Life path of 43years old female from Stara Pazova

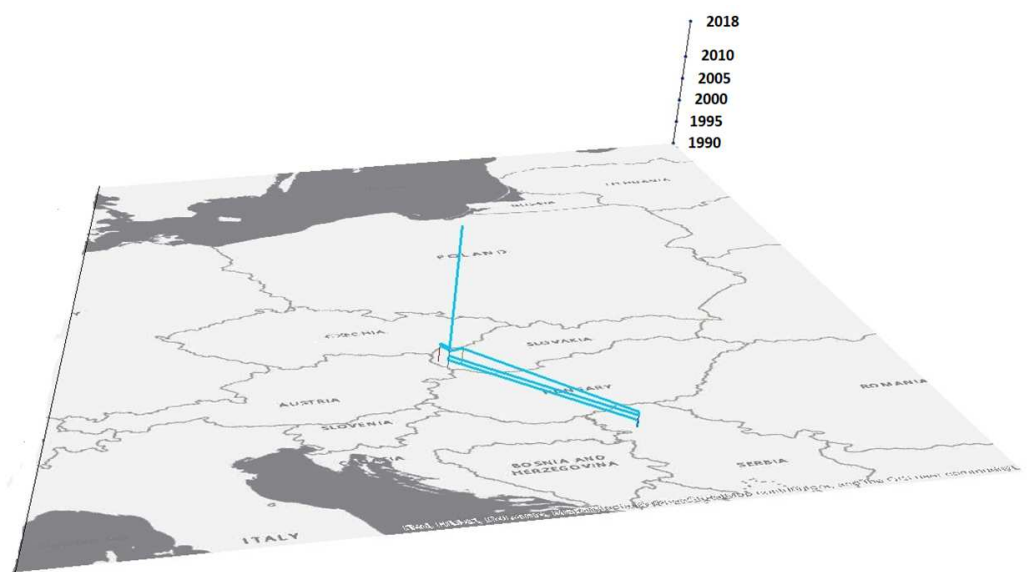

Fig. 3. Life path of 60 years old man from Bački Petrovac

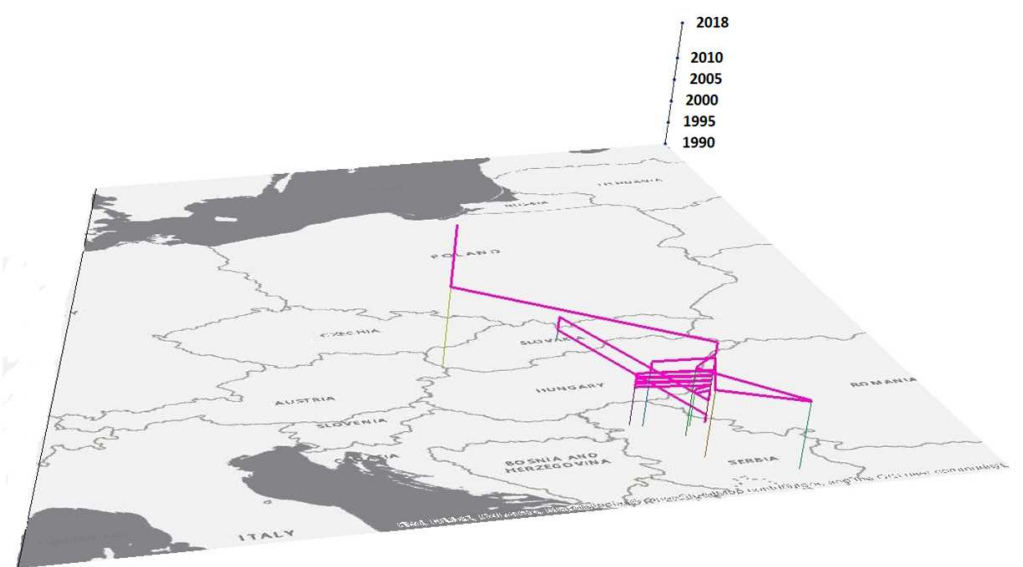

Fig. 4. Life-path of 37 years old man from Jánošik 
Then she came back to Bački Petrovac as a single person (September 2000 - September 2001). Due to the decision to continue her education at the university, she moved to Belgrade (October 2001 - mid-October 2003). She interrupted the courses of graphic design in the second half of October 2003, and tried to apply for a job. For job search, she first moved to hometown and then to Novi Sad (January 2004 till mid-May 2005) and later to Bratislava (mid-May 2005). Because there was another opportunity to stay abroad for several months, she decided to travel abroad and stay with her husband almost half a year (April - October 2011) in Manchester in the United Kingdom, from where they returned to Bratislava in October 2011. At present, they feel at home in Banská Bystrica (since mid-December 2014) and would return to Vojvodina only in the case of similar conditions that existed during the former Yugoslavia in the 1980s.

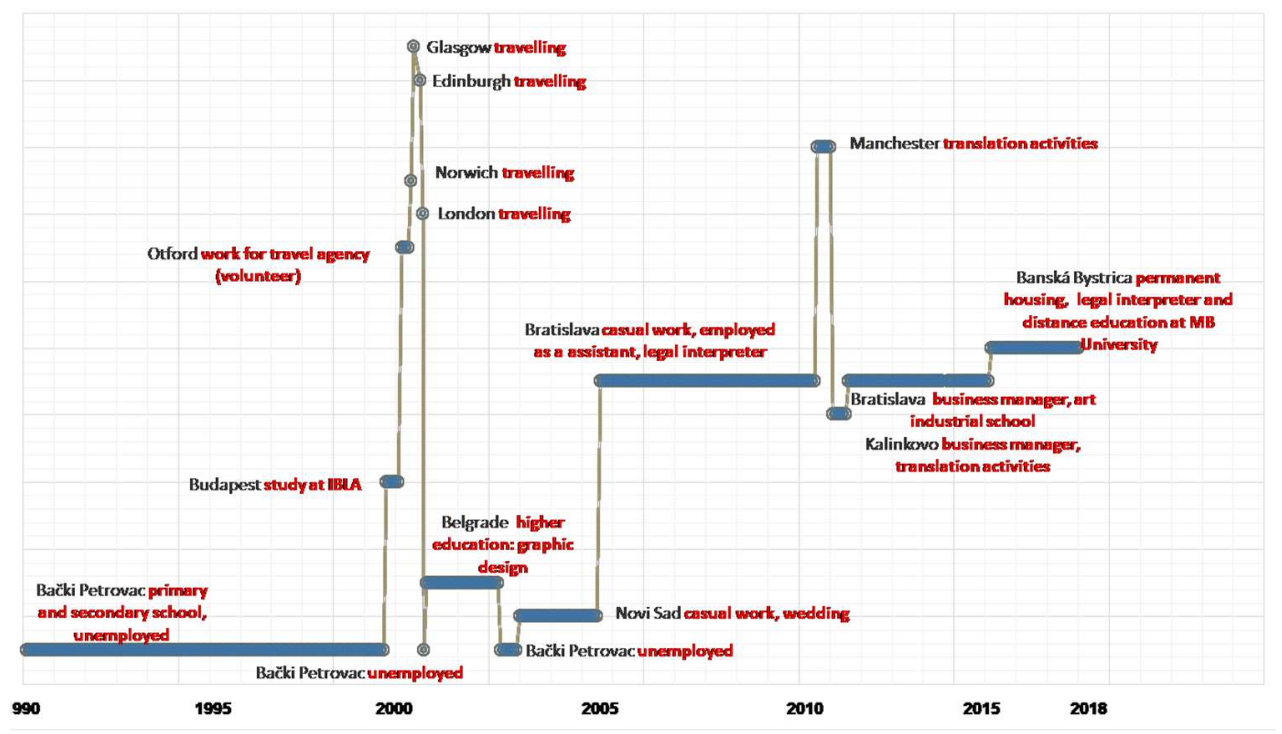

Fig. 5. Life chart of 39 years old female from Bački Petrovac

Analysing results of the applied mixed-methods approach using time-space records, semi-structured interviews and simple observations we can state (similar to Marušiak and Zlatanović 2020 in their study) that the main motivation (push factors) for the migration of Slovaks from Vojvodina to Slovakia during the 1990s was to avoid the difficulties and hardships of war in former Yugoslavia. Later, the difficult political and economic situation in Serbia combined with the unfavourable life prospects of our respondents, became an important motivation for migration. The main pull factors for choosing Slovakia included the relatively small administrative barriers, partial or complete knowledge of a language or linguistic proximity, as well as the presence of family or friendly ties in Slovakia. The improved political and economic situation in Slovakia after 1998 and later the accession to the EU was a significant factor that influenced the widening gap between the quality of life in Serbia and Slovakia. In addition to better material well-being, a better functioning public administration and public services, a more flexible labour market and a more transparent legal environment in Slovakia have become the motivating factors. 
The analysis of the responses from the semi-structured interviews also shed light on some details related to the perception of migrations to Slovakia. Because all respondents experienced the period of war conflicts in the former Yugoslavia in some way, they were asked: Did the conflicts in the former Yugoslavia have a direct impact on your decision to move out from Vojvodina? Twelve persons (more than one third) pointed out that the conflict had directly affected their decision to move. People in fragile and conflict-affected country feel that emigration will provide greater security and enable a higher quality of life. Thirty-nine years old female stated: "After the war, the situation in Serbia remained difficult and it was impossible to think about a better future. I planned to leave her permanently since the war ended, since 1999." The response of forty-five years old male was: "At that first moment, it influenced my decision to go to study abroad." and the answer of the 54-year-old man was: "Yes, because of the situation there. It was chaos ...". Events that occurred on the territory of former Yugoslavia have influenced migration to Slovakia. For 22 persons it was the major reason. Often mentioned reasons were: to avoid potential conflict in the future, get a better job, education or to help family members.

To the question: "Have you already had someone in Slovakia who helped you with your arrival?", the vast majority of interviewed (almost three fourths) said that they found jobs, accommodation or solved other problems through siblings, family, relatives, friends or local church (in one case). Only more than one fourth of respondents, said that at the time they came to Slovakia no one had helped them.

In response to the question "Did you face any problems after arrival to Slovakia?" more than two thirds of interviewees said that they have had problems. Some of these troubles pertain to daily matters. Of the issues they mentioned, it is worth mentioning what has also appeared in the studies Zlatanović and Marušiak (2017) and Marušiak and Zlatanović (2020): adaptation to the Slovak society, new environment, way of life, language pitfalls which caused unpleasant situation in communication, bureaucracy at the Foreign Police or the problems with colleagues. We give some examples: "I had problems with the authorities, who could not understand how I can be Slovak when I was born in Serbia, they called me Serbian and were not willing to help." (Female, 39), "Exaggerated bureaucracy at offices and fear of some Slovak citizens of foreigners." (Female, 37).

One of the other questions focused on the relationship of Slovaks from Vojvodina with the inhabitants of Slovakia was: "How do you assess the behaviour of the Slovak population towards you? (What kind of opinion they have about you)?" Majority of our respondents had positive opinion on behaviour of Slovaks towards Slovaks from Vojvodina, only small part of them have mentioned bad experiences after coming to Slovakia. In the eyes of foreign Slovaks, population of Slovakia is friendly, especially when they overcome their first fear or initial suspicions about somebody different. They are willing to help, but many of them know very little about the Slovaks from Vojvodina. ("We, the foreign Slovaks are largely irritated by the fact that Slovaks in Slovakia know very little or nothing at all about expatriate communities." - 40 years old female).

In the semi-structured interviews, our respondents also characterized their perception of relations with the people of Slovakia. The most frequent answers to this question were that generally they recognise their relationship with domicile Slovak residents as friendly and positive. In several answers, the respondents expressed their experience, which says that Slovaks are also narrow-minded, racists are 
among them, they have problems with foreigners and also that their mentality is different.

Last question in our interview was: What reasons would influence your decision to return to Vojvodina? The most serious reasons for returning could be if one of the relatives would need help or economic support. Most respondents did not plan to return to Vojvodina. Some of them mentioned that the reasons for their return to their country of birth could be "spiritual calling", retirement, good job and financial security in Serbia, or maybe a war in Slovakia or if Slovakia should deport them.

The analysis of the spatio-temporal records of our respondents between 1990 and 2018 showed a relatively large variability between the patterns of spatiotemporal behaviour. In the first years, trajectories with a wider spatial extent prevailed; later migration routes were limited to the movement within Slovakia and its neighbours and between localities in the new homeland Slovakia and the localities in Vojvodina.

To some extent in line with the results of the Marušiak and Zlatanović surveys, respondents in our research stated that leaving for Slovakia means a solution to their individual safety and prosperity. "Slovakia is thus becoming a safe country for the members of this migrant group, given the situation in which they found themselves in their country of origin" (Marušiak and Zlatanović (2020, p. 156).

\section{DISCUSSION AND CONCLUSION}

In the future, the diasporas of Slovaks as well as diasporas in other Central and Eastern European nations in several developed countries may cause some return migration. Judging from the magnitude of this phenomenon in recent years, Kupiszewski et al. (2013) assume that these flows will be rather limited in size, because the ethnic factor of international migration within Europe is going to considerably decrease in significance.

Our findings identified some attitudes of respondents towards emigration. At the time of decision, they would preferably migrate anywhere outside Serbia, mostly to Slovakia but not outside Europe. This could be explained by the overall bad socio-economic situation in Serbia and also by their limited migration experiences and residencies abroad. Slovakia is the country to which they feel close, the official language is their mother language, some of them studied in Slovakia and some of them hold Slovak citizenship. According to the respondents, migration to Slovakia brought some negatives, such as adaptation to the Slovak society, new environment, way of life, language pitfalls which caused an unpleasant situation in communication, bureaucracy at the Foreign Police or the problems with colleagues.

The results of our survey are in line with the concluding remarks of research published by Marušiak and Zlatanović (2020, p. 155). „The migration of Vojvodina Slovaks to Slovakia is perceived also as a security issue from several aspects from the point of view of individual security as well as from the point of view of the security of Serbia as a country of origin and of Slovakia which ceases to be only an "external homeland" for a great part of the community members, as it is also their country of destination and is becoming their new homeland".

Wars in former Yugoslavia had long term effects not only on the populations in the conflict zones, but also on populations beyond these territories. Significant part 
of the post-conflict geographical research is focused on the political, social and economic consequences of wars (Uher 2018). In this paper a special attention was given to selected behavioural geographical aspects. The long-term impacts of the wars in former Yugoslavia are not entirely clear, but our behavioural geographical research shows that there are certain differences between the motivations and life paths of Serbs from non-Serbian republics of the former Yugoslavia (see Uher and Ira 2019), the motivations and life-paths of Bosniaks (Uher and Ira 2021) and inhabitants from Vojvodina of Slovak origin. Patterns of post-war spatio-temporal behaviour of Slovaks from Vojvodina are largely influenced by their origin and the emerging type of new relations with the country of their ancestors. It can be stated that part of the migration of the Vojvodina's Slovaks has the nature of "reemigrations".

The time-space records (time-space activity diaries) have proven to be an effective instrument for a sensible analysis of life-paths of individuals. The detailed life chart provided an information not only on challenging but also on stressful life events. These techniques enabled to recall and discuss difficult situations and stressful events in order to obtain a comprehensive picture of the entire life situation of a small sample of Slovaks from Vojvodina who currently live in Slovakia.

The role of the time-geographic techniques to understand time-space processes and to track individual's existence in the time-space emerges again in various (and in some cases new) contexts. Individuals are entering new situations and may experience social and perceptual unease and stress, which can be felt differently in specific population groups (ethnic minorities, threatened persons, economically vulnerable population, and so on). Therefore, several time-geographic concepts seem to gain new qualities, significance and meaning (Klapka et al. 2020).

This work was supported by the Scientific Grant Agency VEGA (grant number 2/0024/21). The authors would like to thank Dr D. Szatmári from the Institute of Geography, SAS for his helpful advices on visualization issues (Figs. 2 -4) in this paper.

\section{REFERENCES}

BENŽA, M., SLAVKOVSKÝ, P., STOLIČNÁ, R. (2006). Atlas tradičnej kultúry slovenských menšín v strednej a južnej Európe. Nadlak (Vydavatel'stvo Ivan Krasko).

BOTIK, J. (2011). Dolnozemski Slováci. Tri storočia vyst'ahovaleckých osudov, spôsobu života a identity Slovákov v Mad’arsku, Rumunsku, Srbsku a Bulharsku. Nadlak (Vydavatel'stvo Ivan Krasko).

BOYLE, P. (2009). Migration. In Kitchin, R., Thrift, N. eds. International Encyclopedia of Human Geography, Vol. 7. Amsterdam and Oxford (Elsevier), pp. 96-106.

COHEN, N., ARIELI, T. (2011). Field research in conflict environments: Methodological challenges and snowball sampling. Journal of Peace Research, 48, 4, 423-435. DOI: $10.1177 / 0022343311405698$.

CRESSWELL, T. (2013). Geographic thought: A critical introduction. Chichester (WileyBlackwell).

COUCLELIS, C. (1999). Space, time, geography. In Longley, P. A. et al. eds., Geographical information systems, principles and technical issues. New York (Wiley ), pp. 29-38.

DANIELS, S., NASH, C. (2004). Lifepaths: geography and biography. Journal of Historical Geography, 30, 449-458. DOI: 10.1016/S0305-7488(03)00043-4.

DÍAZ-MUNOZZ, M. A., SALADO-GARCÍA, M. J., DÍAZ-CASTILLO, C. (1999). A teaching approach to time-geography: Some results of an educational experiment. GeoJournal, 48, 159-166. 
DIVINSKÝ, B. (2007). Zahraničná migrácia v Slovenskej republike. Vývojové trendy od roku 2000. Bratislava (Výskumné centrum Slovenskej spoločnosti pre zahraničnú politi$\mathrm{ku}$, n.o.).

DIVINSKY, B., ZACHAR PODOLINSKÁ, T. et al. (2018). Globe inMotion - Patterns of international migration: Similarities and differences. Bratislava (Institute of Ethnology and Social Anthropology, Slovak Academy of Sciences).

DRBOHLAV, D., UHEREK, Z. (2007). Reflexe migračních teorií. Geografie - Sborník České geografické společnosti, 112, 125-141.

ELLEGÅRD, K. (1999). A time-geographical approach to the study of everyday life of individuals - a challenge of complexity. GeoJournal, 48, 167-175.

ELLEGÅRD, K. (2018). Thinking time geography: Concept, methods and applications. London (Routledge). DOI: https://doi.org/10.4324/9780203701386.

ELLEGÅRD, K. (2019). Introduction: The roots and diffusion of time-geography. In Ellegård, K., ed. Time geography in the global context, an anthology. London and New York (Routledge), pp. 1-18. DOI: https://doi.org/10.4324/9780203701393.

FILADELFI, S. (2012). Slovenská menšina v krajinách bývalého Uhorska v období 1711 1918. Klaudyán: internetový časopis pro historickou geografii a environmentální dějiny. 8-9(1), 26-42.

FRÄNDBERG, L. (2008). Paths in transnational time-space: Representing mobility biographies of young Swedes. Geografiska. A nnaler B, 90, 17-28.

GOODMAN, L. A. (1961). Snowball sampling. A nnals of mathematical statistics, 32, 148 170. DOI: $10.1214 /$ aoms/1177705148.

GOLLEDGE, R. G., STIMSON, R. J. (1997). Spatial behaviour: A geographical perspective. New York and London (The Guildoford Press).

GURŇÁK, D. (2007). Vývoj politickej mapy stredovýchodnej a juhovýchodnej Európy historickogeografická analýza. Bratislava (Kartprint).

HAI, I., ed. (2016). Qualitative research methods in human geography. Don Mills, Ontario (Cambridge University Press).

HÄGERSTRAND, T. (1967). Innovation diffusion as a spatial process. Chicago (University of Chicago Press).

HÄGERSTRAND T. (1970). "What about people in regional science?". Papers of the Regional Science Association, 24, 6-21. DOI: 10.1007/BF01936872.

IOM (2019). World Migration Report 2020. Geneva (International Organization for Migration), [Online]. Available: https://publications.iom.int/system/files/pdf/wmr 2020.pdf [accessed 3 December 2020].

IRA, V. (2001). Geografia času: prístup, základné koncepty a aplikácie. Geografický časopis, 53, 231-246.

JANSKÁ, E., DRBOHLAV, D. (1999). Reemigrace Volyňských Čechů. Geografie - Sbornik $\check{C} G S, 104,106-121$.

KAPLAN, C. D., KORF, D., STERK, C. (1987). Temporal and social contexts of heroinusing populations an illustration of the snowball sampling technique. The Journal of Nervous and Mental Disease, 175, 566-574. DOI: 10.1097/00005053-19870900000009.

KLAPKA, P., ELLEGÁRD, K., FRANTÁL, B. (2020). What about Time-Geography in the post-Covid-19 era? Moravian Geographical Reports, 28, 238-247. DOI: https:// doi.org/10.2478/mgr-2020-0017.

KUPISZEWSKI, M., BIJAK, J., KICINGER, A. (2013). The use of international migration theories in migration forecasting - A practical approach. In Kupszewski, M., ed. International migration and the future of populations and labour force resources in Europe. The Springer series on demographic methods and population analysis 32. Dordrecht (Springer Science and Business Media), pp. 35-56. DOI: 10.1007/978-90-481-894893.

LENNTTORP, B. (1999). Time-geography - at the end of its beginning. GeoJournal, 48, 155-158. 
LUNDÉN, T. (2003). States, networks and individual life paths. In Clark, E., Hallin, P. O., Widgren, M., eds., Tidrumsfragment: en vänbok till Bo Lenntorp. Stockholm and Lund (Institutionen för kulturgeografi och ekonomisk geografi, Lunds universitet), pp. 137159.

MARUŠIAK, J., ZLATANOVIĆ, S. (2020). Slovakia as a safe country - The perspective of the Slovak community members of Vojvodina. Slovenský národopis, 68, 136-160. DOI: https://doi.org/10.2478/se-2020-0008.

MERRIMAN, P. (2012). Human geography without time-space. Transactions of the Institute of British Geographers, 37, 13-27.

PRED, A. (1981). Social reproduction of the time-geography of everyday life. Geografiska Annaler, Series B Human Geography, 63, 5-22.

PRED, A. (2005). Hägerstrand matters: Life(-path) and death matters - some touching remarks. Progress in Human Geography, 29, 328-332. DOI: 10.1177/03091325050 2900310.

ROCHOVSKÁ, A., KÁČEROVÁ, M., ONDOŠ, S. (2014). Výskumné metódy v humánnej geografii a ich aplikácie, Vysokoškolská učebnica. Bratislava (Univerzita Komenského v Bratislave).

SCHWANEN, T. (2009). Time-space diaries. In Kitchin R, Thrift, N., eds., International Encyclopedia of Human Geography Vol. 11. Amsterdam and Oxford (Elsevier), pp. 294-300.

SCHWANEN, T., KWAN, M-P. (2012). Critical space-time geographies. Thinking the spatiotemporal. Environment and Planning A, 44, 2043-2048. DOI:10.1068/a45437.

SIRACKÝ, J. (1980). Slováci vo svete. Martin (Matica slovenská).

STATISTICAL OFFICE OF THE REPUBLIC OF SERBIA (2013). 2011 Census of population, households and dwellings in the Republic of Serbia. Population, religion, mother tongue and ethnicity. Belgrad (Statistical Office of the Republic of Serbia).

SUNNQVIST, C., PERSSON, U., LENNTORP, B., TRÄSKMAN-BENDZ, L. (2007). Time-geography: A model for psychiatric life charting? Journal of Psychiatric and Mental Health Nursing, 14, 250-257. DOI: https://doi. org/10.1111/j.1365-2850. 2007.01071.x.

SUNNQVIST, C., RÄMGÅRD, M., ÖRMON, K. (2020). Time geography, a method in psychiatric nursing care. Issues in Mental Health Nursing, 41, 1-7. DOI: 10.1080/ 01612840.2020 .1757795$.

SUROVÁ, S. (2016). The national and ethnic identifications among Slovak diaspora in Serbia: Stranded in between state and ethnicity? Working paper. Bratislava (ERTSE Stiftung).

SUROVÁ, S. (2018). National and ethnic identifications among the Slovak diaspora in Serbia: Stranded between state(s) and ethnicity? Nationalities Papers, 46, 1081-1100. DOI: $10.1080 / 00905992.2018 .1488825$.

UHER, A. (2018). Human behaviour in the territory affected by war conflict: Theoreticalmethodological notes and examples of war and post war life courses. Montenegrin Journal for Social Sciences, 2, 109-121.

UHER, A., IRA, V. (2019). Life-paths of Serbs in the context of conflicts in former Yugoslavia. Folia Geographica, 61(2), 25-44.

UHER, A., IRA, V. (2021). The consequences of armed conflicts on life paths of Bosniaks from Eastern Bosnia. AUC Geographica, 56, 95-107.

YEAGER, C. D., STEIGER, T. (2013). Applied geography in a digital age: The case for mixed methods. Applied Geography, 39, 1-4, DOI: 10.1016/j.apgeog.2012.12.001.

ZLATANOVIĆ, S., MARUŠIAK, J. (2017). 'Povratna'migracija vojvođanskih Slovaka i pitanje pripadnosti. Glasnik Etnografskog instituta SANU, 65, 653-668. DOI: 10.2298/ GEI1703653Z.

Zákon č. 70/1997 Z.z. o zahraničných Slovákoch [Act No. 70/1997 Coll. on Foreign Slovaks]. 
Zákon č. 474/2005 Z.z.o Slovákoch žijúcich v zahraničí a o zmene a doplnení niektorých zákonov [Act no. 474/2005 Coll., on Slovaks living abroad].

https://www.sio.vojvodina.gov.rs/index.php/linkovi/linkvi-opstine

\author{
Vladimír Ir a, Ana Uher
}

\title{
MIGRAČNÉ BIOGRAFIE SLOVÁKOV Z VOJVODINY PO ROKU 1990 Z POHLADU GEOGRAFIE ČASU
}

\begin{abstract}
Životná história migrantov, ktorých životné cesty boli ovplyvnené významnými politickými a spoločenskými udalost’ami, je jedným z prvoradých záujmov humánnej geografie a d'alších spoločenských a humanitných vied. Ciel'om tohto príspevku je ilustrovat', ako môže byt' geografia času využitá pri identifikácii vzorcov správania jednotlivcov vo vzt’ahu $\mathrm{k}$ určitým situáciám $\mathrm{v}$ čase a priestore (mieste). Výskum sa uskutočnil na malej vzorke vojvodinských Slovákov ( $\mathrm{n}=34,19$ žien a 15 mužov), ktorí v súčasnosti bývajú na Slovensku. Ide o potomkov Slovákov, ktorí sa z územia bývalého Horného Uhorska prest’ahovali pred viac ako dva a pol storočiami na Dolnú zem do Vojvodiny. Pri zostavovaní 3D životných dráh (life-paths) a životných máp (life charts) sa použili dáta získané z rozhovorov a časovo -priestorových záznamov ich činností. Prístup, ktorý sa používa v geografii času, zabezpečuje určité množstvo informácií umožňujúcich vytvárat' širší obraz o živote človeka s ciel'om identifikovat' aj jeho sociálne, ekonomické a behaviorálne aspekty (vrátane motivácie migrovat'). V našej štúdii ide o osoby, ktoré zažili vojnový konflikt v bývalej Juhoslávii a následne boli ovplyvnené množstvom politických, právnych, sociálnych a ekonomických zmien. Zistenia z výskumu ukazujú, že tento druh „schém časti životného cyklu“ ponúka komplexný a štruktúrovaný obraz. Podrobne sa opisujú zmeny v životných situáciách $\mathrm{v}$ jednotlivých časových obdobiach, kde geografické poloha (miesto) slúži ako dôležitá „životná stanica“".
\end{abstract}

Ako príklad vizuálnej interpretácie časovo-priestorových záznamov denníkov v 3D grafoch sme vybrali troch respondentov slovenského pôvodu zo Starej Pazovy (obr. 2), Báčskeho Petrovca (obr. 3) a Jánošika (obr. 4). Vybraná skupina troch respondentov, zastúpená jednou ženou a dvoma mužmi, predstavuje rôzne typy životných ciest ovplyvnených rozličným prostredím, rôznymi životnými situáciami a d’alšími faktormi. Vertikálna os v grafoch predstavuje časovú dimenziu (časový kontext). Určité činnosti človeka sa odohrávajú v konkrétnych geografických kontextoch (vyjadrené d’alšími dvoma dimenziami). Každé prerušenie alebo odklon znamenalo zmenu smeru pohybu. Časové rozpätie analýzy použitej pri konštrukcii 3D grafov bolo od roku 1990 do roku 2018. Pri hodnotení celého súboru respondentov možno konštatovat', že pred vojnou neboli zaznamenané žiadne významné zmeny v mieste života, naopak v povojnovom období boli pohyby vel'mi časté a vel'a z nich smerovalo na Slovensko. Životné dráhy troch vybraných respondentov sú v článku podrobnejšie analyzované a graficky dokumentované 3D grafmi (obr. 2 - 4). V prípade štvrtej respondentky z Báčskeho Petrovca (obr. 5) je 28-ročný segment jej životnej dráhy podrobnejšie analyzovaný aj prostredníctvom tzv. životnej mapy (life chart).

Vzorce časovo-priestorového správania vojvodinských Slovákov po roku 1990 (v súčasnosti bývajúcich na území Slovenska) sú do značnej miery ovplyvnené ich pôvodom a vznikajúcim typom nových vzt'ahov s krajinou ich predkov. Možno konštatovat', že čast' migrácie vojvodinských Slovákov má povahu „reemigrácií“. Medzi motivačnými dôvodmi na dlhodobý alebo trvalý pobyt na Slovensku vo väčšine prípadov môžeme nájst' bud' pokračovanie vo vysokoškolskom štúdiu, alebo hl'adanie zamestnania, ktoré im dáva ovel'a lepšie finančné príležitosti. Motiváciu migrovat' ovplyvnili aj bezpečnostné obavy na základe skúseností, najmä počas najtvrdších vojenských zásahov v rokoch 1991 - 1995 (tab. 1). Slovenskí migranti z Vojvodiny môžu byt' významným sociálno-kultúrnym, občiansko- 
politickým a ekonomickým prínosom pre Slovensko a môžu prispiet' aj k určitým zmenám $\mathrm{v}$ ich komunitách $\mathrm{v}$ regióne ich pôvodu vo Vojvodine.

Záznamy časovo-priestorových aktivít sa ukázali ako efektívny nástroj pre zmysluplnú analýzu životných dráh jednotlivcov. Životné mapy poskytli informácie nielen o náročných, ale často aj o stresujúcich životných udalostiach. Tieto techniky umožnili získat' komplexný obraz za dvadsat'osemročné obdobie. Metódy geografie času, ktoré umožňujú pochopit' časovo-priestorové procesy a sledovat' existenciu jednotlivca v časopriestore, sa znovu objavujú v rôznych a v niektorých prípadoch aj nových kontextoch. Jednotlivci vstupujú do nových situácií a môžu ich vnímat' nielen osobne, ale aj v kontextu skúseností v určitých skupinách obyvatel'stva (etnické menšiny, ohrozené osoby, ekonomicky zranitel'né obyvatel'stvo atd'.). Ukazuje sa, že niektoré koncepty geografie času nadobúdajú nové kvality, dôležitost' a význam. 